\title{
DA ESCRAVIDÃO À LIBERDADE: A HISTÓRIA DE MARIA DA CONCEIÇÃO, ROUBADA E ESCRAVIZADA (NAZARÉ, 1830-1876)
}

From Slavery to Freedom: The story of Maria da Conceição, abducted and enslaved (Nazaré, 1830-1876)

De La esclavitud a La Libertad: La historia de Maria da

Conceição, raptada y esclavizada (Nazaré, 1830-1876)

\section{VIRGINIA QUEIROZ BARRETO ${ }^{*}$}

http://dx.doi.org/10.1590/S2178-14942019000100006

\footnotetext{
I Universidade do Estado da Bahia (UNEB) - Salvador - BA, Brasil.

* Universidade do Estado da Bahia (UNEB), Departamento de Ciências Humanas - Campus I, Salvador - BA, Brasil. (vqbarreto@gmail.com), ORCID: https://orcid.org/0000-0002-8305-974X
}

Artigo recebido em 15 de novembro de 2018 e aceito para publicação em 12 de fevereiro de 2019. 


\title{
RESUMO
}

Em 1830, Maria da Conceição, moradora da Vila de Nossa Senhora da Ajuda de Jaguaripe, recôncavo sul da Bahia, foi vítima da prática ilícita de "reduzir pessoa livre à escravidão". No longo período de 1830 a 1876, permaneceu ilegalmente como escrava. No Brasil, a legislação em vigor poderia ajudar a referida "escrava" na tentativa de obter a sua liberdade de volta, mas o caminho empreendido por ela até a Justiça, na qual teve que provar sua condição de mulher livre, levou longos e penosos 46 anos. Essa história será contada a partir do processo civil de ação de liberdade movido por ela em 1876. Os dados localizados em tal processo e o cruzamento de outras fontes foram o fio condutor para entender as tramas vividas por essa mulher que, na contramão de uma sociedade escravista marcada pela hierarquia de gênero, conseguiu alcançar seus objetivos, revelando, assim, que em diversas situações, o resultado das relações de poder nem sempre foi negativo para as mulheres. Sua história de vida possibilitou, ainda, trazer à tona muitas outras histórias de sujeitos que compuseram o universo vivido por essa personagem.

PALAVRAS-CHAVE: Escravidão; Liberdade; Recôncavo baiano; História das mulheres.

\begin{abstract}
In 1830, Maria da Conceição, a resident of the village of Nossa Senhora da Ajuda de Jaguaripe, in the southern region of the Bahia cove, was a victim of the illegal practice of 'reducing free people to slavery.' In the long period between 1830 and1876, she lived as anillegal slave. In Brazil, the legislation in effect at the time could help the aforesaid 'slave' tryto gain her freedom back, but the path she took to Justice, in whichshe had to prove her status as a free woman, took a long and arduous 46 years. This story will be told based on the action of freedom civil action moved by her in 1876. The data located in this civil action and the crossing of other sources were the guidelines to understand the situations lived by this woman who, going against a slave society marked by gender hierarchy, was able to achieve her goals, thus revealing that in several situations the result of power relations has not always been negative for women. Her life story has also made it possible to bring to light many other stories of the individual swho were part of the universe in which this character lived.
\end{abstract}

KEYWORDS: Slavery; Bahia cove; Women's history.

\section{RESUMEN}

En el año 1830, Maria da Conceição, moradora del pueblo de Nossa Senhora da Ajuda de Jaguaripe, en la ensenada sur de Bahía, fue víctima de la práctica ilícita de "reducir a la persona libre a la esclavitud". En el largo periodo de1830 a 1876, permaneció ilegalmente como esclava. En Brasil, la legislación en vigor podría ayudar a la referida "esclava" en su intento de reconquistar la libertad, pero el camino hecho por ella hacia la Justicia, en la cual tuvo que probar su condición de mujer libre, llevó largos y penosos 46 años. Esa historia será contada a partir de la demanda civil de acción de libertad presentada por ella en 1876. Los datos localizados en tal demanda y el cruce con otras fuentes han sido el hilo conductor para comprenderlas situaciones vividas por esta mujer que, a contramano de una sociedad esclavista marcada por la jerarquía de género, logró alcanzar sus objetivos, revelando, por lo tanto, que en diversas situaciones el resultado de las relaciones de poder ni siempre ha sido negativo para las mujeres. Su historia de vida posibilitó aún sacar a la luz muchas otras historias de individuos que compusieron el universo vivido por ese personaje.

PALAVRAS ClAVE: Esclavitud; Libertad; Ensenada de Bahía; Historia de las mujeres. 
$\mathrm{N}$ os primeiros dias do mês de junho do ano de 1876, Maria da Conceição, de cor "cabra", 56 anos de idade, escrava de dona Maria Josefina de Andrade, moradora na freguesia de Santo Antônio de Jesus, conseguiu permissão de sua senhora para ir à vila de Jaguaripe, ocasião em que a mesma deu entrada em uma ação de liberdade contra os seus "pretensos senhores".

A princípio, a ação proposta por Maria da Conceição, em que uma escrava reivindicava 0 direito à liberdade por considerar injusto o cativeiro em que se encontrava, me pareceu corriqueira. No entanto, uma leitura mais minuciosa das 424 páginas que compõem o seu processo, iniciado em junho de 1876, revelou uma situação bem diferente daquelas que levaram muitos escravos à Justiça.

A autora não alegava discordar do preço fixado por seu senhor para a compra de sua alforria; não alegava maus-tratos; não tinha sido liberta de pia, e continuava em cativeiro mesmo após a morte do seu senhor; e não alegava ter sido reescravizada, mas declarava ter sido escravizada ilegalmente. Nascida em 1830, filha da liberta Antonia Francisca, Maria revelou no documento judicial "ter nascido de ventre livre", ter sido "furtada" aos 10 anos de idade na vila de Jaguaripe, onde vivia com sua mãe, e ter sido vendida como escrava a Felix José Barreto, na freguesia de Santo Antonio de Jesus, onde permaneceu cativa por 46 anos de sua vida. Assim, a ação proposta por Maria da Conceição apresentava um elemento novo: a escravização de pessoa de cor, livre.

Além dessa peculiaridade, outro ponto também chamou a minha atenção: a ação proposta por ela não requeria apenas a sua liberdade, mas, igualmente, a de suas duas filhas e seus sete netos, todos nascidos na escravidão, entre os anos de 1830 e 1875 . Portanto, essa era uma ação que envolvia diretamente a liberdade de toda uma família escravizada ilegalmente no recôncavo baiano, totalizando dez indivíduos em posse de senhores diversos. Em termos legais e concretos, estes fatos configuravam uma ação complicada.

Já nas primeiras páginas daquele processo judicial iniciado em 1876, que consumiu longos dias de uma minuciosa leitura, foi se descortinando a história da vida de quatro gerações de mulheres que vivenciaram a escravidão e a liberdade no recôncavo baiano durante o Oitocentos. Nas entrelinhas do processo, observa-se a ilegalidade da condição escrava imposta a três dessas quatro gerações, a partir de uma atrocidade cometida nas primeiras décadas do século XIX. Embora numerosas pesquisas tenham tratado das ações de liberdade movidas por escravos, revelando uma variedade de motivações (Chalhoub, 1990; Mattos, 2013; Abrahão, 1992; Grinberg, 2008), situações como a vivida por Maria da Conceição - mulher livre de cor, vendida como escrava -, pouco documentadas pela historiografia, contribuem não apenas 
para aprofundar a análise sobre as diversas formas de ilegalidade às quais foram submetidos os sujeitos escravizados no Brasil, como também abre uma brecha por onde podemos espreitar a construção de importantes redes de proteção, laços de solidariedade e formas de sobrevivência criados por mulheres negras no difícil cotidiano da vida escrava.

Contrariando a ideia de que aceitavam a dominação com passividade (Paixão; Gomes, 2012: 298), mulheres negras escravizadas, como Maria da Conceição, marcaram suas vidas reinventando formas de resistência, construindo ambientes de solidariedade, articulando meios de preservar a própria vida e a de seus familiares. No Brasil, estudos sobre a vida cotidiana de mulheres na escravidão, os caminhos trilhados por elas para a conquista da liberdade e seus significados lançaram luz sobre suas práticas sociais, revelando, entre outras coisas, 0 papel primordial que ocuparam no mercado informal de trabalho e o papel das identidades de gênero (Dias, 1984; Soares, 1996; Farias, 2015; Cowling, 2012).

No caso aqui estudado, a documentação encontrada já sinalizava a possibilidade de se recuperar, por meio de uma personagem singular, a trajetória de uma família escravizada ilegalmente no mundo rural do sul do Recôncavo Baiano do século XIX. No entanto, fazia-se necessário varrer os arquivos da região e da capital da Bahia em busca de outros documentos que trouxessem mais informações sobre a região e sobre outros sujeitos que, de uma forma ou de outra, estivessem ligados a essa família.

Além da já citada ação de liberdade, localizamos outros documentos que envolviam a família de Maria da Conceição, entre eles, os assentos de batismo, inventários, testamentos e uma provável ação criminal contra Antonia Francisca, mãe de Maria da Conceição. Documentos como os autos criminais de Jaguaripe, situados entre os anos de 1830 e 1876, envolvendo outros sujeitos, também foram escrutinados, e trouxeram elementos importantes para se compreender a escravidão naquela localidade, fazendo emergir não apenas a relação básica entre escravos e senhores, mas toda uma rede mais ampla de conexões que os envolvia: laços afetivos, cadeias hierárquicas, relações de vizinhança e de parentesco. Tais documentos revelaram também a existência de uma linha tênue que marca a fronteira entre a escravidão e a liberdade na região.

\section{UMA VIDA, MUITAS HISTÓRIAS}

E m 27 de novembro de 1820, Antonia Francisca, liberta, natural e moradora na Vila de Nossa Senhora D'Ajuda de Jaguaripe, levou em seus braços a pequena Maria da Conceição, sua filha recém-nascida, para receber aquele seu primeiro sacramento cristão, o qual, anos mais tarde, serviria para provar sua condição de nascida livre. 
A capela escolhida para o batismo ficava a "três léguas de distância" da vila de Jaguaripe, localizada na fazenda Santo Antônio das Barreiras e, ao que tudo indica, os arranjos para tal batismo em uma capela na qual "ninguém as conhecia" foram feitos por Pedro Agapito, sacristão e amásio de Antonia Francisca à época. Esses arranjos, segundo a defesa dos réus no processo de ação de liberdade, serviram para esconder a sua real condição: escrava e não liberta. Eis algumas ponderaç̃oes sugeridas por esta pesquisa, caso considerássemos que a defesa tivesse razão: como poderia uma escrava ter se mantido tanto tempo longe do cativeiro, posto que Maria, morando com sua mãe na vila de Jaguaripe, alegava ter sido roubada aos 10anos de idade?

É fato que a crioula Antonia Francisca, mãe de Maria da Conceição, viveu na condição de escrava de ganho durante 0 tempo em que era cativa, e usufruiu das facilidades que essa condição lhe garantia. É fato, também, bastante documentado pela historiografia da escravidão, que o trabalho de ganho executado por mulheres escravas as aproximava do mundo das libertas, uma vez que essa atividade possibilitava uma maior mobilidade, pouco diferenciando o cotidiano vivido por elas daquele experimentado por mulheres pobres livres e forras (Dias, 1984; Wissenbach, 1998; Soares, 1996; Andrade, 1988).

No sul do Recôncavo Baiano, essa foi uma realidade. A documentação escrutinada sinalizou a presença de mulheres escravizadas ocupando as mesmas funções que as pobres livres e forras. Com autorização de seus senhores, as escravizadas circulavam pelas povoações e vilas da região comprando e vendendo mercadorias, habitavam casas ou quartinhos de aluguel, e estabeleciam seus horários de trabalho. Ainda que tivessem de prestar conta de suas atividades, era, sem dúvida, uma vida mais "livre" do que aquela vivenciada por suas companheiras de condição alocadas nas propriedades rurais da região e submetidas à rotina rígida das lavouras.

Tornar-se escrava de ganho foi, certamente, uma condição que muitas mulheres escravizadas almejavam. As "vantagens" variavam, entre outras, desde a de viver livremente "sobre si" até a de angariar recursos para a compra da liberdade. Assim, tornar-se uma escrava de ganho e poder circular livremente pelas vilas e freguesias da região foi uma conquista que Antonia Francisca não deixou escapar. A permissão concedida por sua senhora Anna de Jesus para "negociar e pagar semanas" - como declararam as testemunhas no processo - foi, sem dúvida, um passo definitivo na busca de sua liberdade. Viver de sua agência, mesmo que de tempos em tempos, de acordo com o contrato estabelecido com sua senhora, tivesse de retornar ao cativeiro para prestar contas do trabalho executado na semana, trazia certa autonomia. Além da flexibilidade dos horários de trabalho, podia administrar seus ganhos, construir espa- 
ços afetivos e, principalmente, deslocar-se por entre as vilas, freguesias e pequenas povoações rurais do sul do Recôncavo Baiano.

Ainda sob o domínio de sua senhora Anna de Jesus, Antonia Francisca penou mercadejando pelas povoações pertencentes ao município de Jaguaripe, vendendo e comprando víveres, atividade que compartilhou, muitas vezes, com outras companheiras de infortúnio, também escravizadas. Como vendedoras ambulantes - sozinhas ou, muitas vezes, em pequenos grupos de duas ou três -, cumpriam uma rotina diária de trabalho que incluía transpor grandes distâncias por difíceis caminhos de barro, enfrentar travessias de rios e encarar as dificuldades impostas pela mata existente naquela região. Esse foi o caso da escrava africana Felicidade, que transitava por entre as diversas povoações daquela localidade mercadejando frutas e verduras "a serviço de seu senhor", como ela mesma declarou ao ser arrolada como informante no processo crime ocorrido em Jaguaripe no ano de 1864'.

Além dos perigos impostos pela atividade realizada, o deslocamento por variadas localidades possibilitou o acesso a importantes relações afetivas e de companheirismo com diversos sujeitos que, no caso de Antonia Francisca, seriam, mais tarde, peças fundamentais na disputa judicial envolvendo sua filha, netos e bisnetos. Ao que tudo indica, o trabalho de ganho praticado por Antonia foi essencial não apenas para a construção de uma importante rede afetiva, pois foi também nas ruas que conseguiu amealhar alguns vinténs "por meio de esmolas que agenciara com o consentimento de Anna de Jesus" sua senhora àquela época, para a compra de sua liberdade, quatro anos antes do nascimento de Maria da Conceição, como afirmam as testemunhas².

Uma vez liberta, sua rotina de trabalho pouco mudou. Continuou mercadejando e residindo na mesma casinha de aluguel na rua do Torce Umbigo, na qual morava quando escrava. Durante o tempo em que ali viveu, Antonia construiu importantes laços de solidariedade com mulheres que, assim como ela, viveram as dificuldades de criar seus filhos sem a presença de um companheiro. Consta, na documentação, que ela teve uma filha parda de nome Umbelinda, de pai ignorado, e que pouco tempo depois engravidou novamente e deu à luz outra menina de nome Maria da Conceição, fruto de um relacionamento com um tal de Manoel Rugeso, morador do Mucujó, povoado ribeirinho próximo à vila de Jaguaripe. Esse relacionamento, assim como o anterior, parece não ter durado muito tempo. Antes mesmo de Maria nascer, Antonia já tinha outro parceiro, o sacristão Pedro Agapito, que a ajudou no batismo da recém-nascida na capela da fazenda de Santo Antonio das Barreiras. Não sabemos quanto tempo durou tal relação; mas, ao que tudo indica, eles já não mais conviviam na época do desaparecimento de Maria, em 1830. 
Mãe de duas crianças, Antonia Francisca revela em sua singular trajetória "uma espécie de sumário de muitas outras trajetórias entrecruzadas e similares" (Paiva, 2002: 16). Assim como ela, outras mulheres cativas cruzaram a fronteira entre a escravidão e a liberdade sem que, no entanto, tivessem mudanças sociais e econômicas significativas em suas vidas. Continuavam pobres, morando em casebres, e, sós, criavam seus filhos, frutos de "tratos ilícitos", gerados no sabor de paixões passageiras. As relações que estas mulheres estabeleceram entre si foram, muitas vezes, favorecidas pela proximidade de suas moradias e pela condição de pobreza em que viveram. A descrição de hábitos diários como ir na fonte buscar água e tirar lenha no mato ou deixar seus filhos aos cuidados de vizinhos, recorrente nas narrativas de testemunhas, réus ou vítimas em diversos processos judiciais, atestam a convivência cotidiana e a importância de tais redes sociais na dura vida de uma mulher pobre. Tratava-se de laços afetivos importantes dos quais poderiam lançar mão sempre que precisassem de apoio, sobretudo em momentos cruciais como o da ação de liberdade, na qual Maria teve de provar sua condição de "nascida livre", 46 anos depois de ter sido roubada e vendida como escrava.

E foi, provavelmente, à procura desse apoio que Maria buscou, em Jaguaripe, localizar pessoas - muitas delas, assim como sua mãe, egressas da escravidão - para atuar como testemunhas na ação de liberdade em que revela a atrocidade vivida por ela em meados de 1830, com apenas 10 anos de idade. Das oito testemunhas indicadas pela defesa no processo, cinco eram moradoras da vila de Jaguaripe desde o tempo em que Maria havia sido roubada em 1830, conheceram sua mãe no tempo da escravidão, e atestaram em juízo a sua liberdade antes do nascimento de Maria. Duas delas, em 1876, já libertas, continuavam morando na mesma vila de Jaguaripe: Úrsula Antonia da Conceição e Rachel de Seixas, africanas com mais de 60 anos de idade.

Vizinhas e parceiras na dura luta pela sobrevivência, Úrsula Antonia da Conceição afirmou, categoricamente, que Antonia, ao dar a luz a Maria da Conceição, "havia quatro anos que se libertara, o que ela, testemunha, sabe por ter conhecido a mesma Antonia Francisca a qual era tida e havida como forra na referida Villa de Jaguaripe". ${ }^{3}$ Naquela época, Úrsula era uma jovem de aproximadamente 18 anos, morava com sua filha em uma casinha na rua do Torce Umbigo, e, ao ser questionada acerca do desaparecimento de Maria, recordou que "no dia seguinte ao desaparecimento, a mãe de Maria foi ter com ela, perguntando-lhe pela autora, dizendo-lhe ter esta desaparecido". ${ }^{4}$

Naquele tempo, a exemplo do que ocorre nas pequenas cidades do interior nos dias de hoje, os acontecimentos tinham grande repercussão. Sabia-se, por exemplo, quem tinha participado desse ou daquele crime, quem era escravo e a qual senhor pertencia, quem 
conseguiu se alforriar e, principalmente, se essa ou aquela mulher era honesta ou não, apenas por ser "voz pública". No dia seguinte ao desaparecimento de Maria, a cidade já comentava o ocorrido sem que se soubesse o seu paradeiro. Em 1877, 47 anos depois do desaparecimento de Maria, Athanasio Rodrigues, natural de Mucujó - localidade próxima à vila de Jaguaripe -, ainda lembrava que "era público e notório na referida Villa o furto da mesma Maria da Conceição". 5

Desqualificados pelos advogados dos réus, por serem, "analphabetas" e "escravas", as testemunhas revelam a proximidade e, até mesmo, certa cumplicidade existente nesses relacionamentos, principalmente entre aqueles que também haviam experimentado trajetórias de vida marcadas pela sujeição e exploração de seu trabalho. 0 relacionamento muito próximo, "quase uma irmandade", desenvolvido pela crioula Antonia na pequena vila de Jaguaripe com seus vizinhos era uma característica das pequenas cidades e vilas do interior do Brasil. Naquela época, e durante todo o século XIX, a vila de Jaguaripe não passava de uma pequena povoação - não dispomos de dados sobre a população na década de 1830, época do desaparecimento de Maria, mas em 1872 a vila contava com uma população de 2.537 pessoas, e, destas, apenas 342 (13\%) eram escravizadas, e o número de pardos e pretos superava o dos brancos. ${ }^{6}$

De fato, outros dados revelam que essa vila pouco se desenvolveu ao longo do século XIX.7 Seus habitantes, homens e mulheres de poucas posses, proprietários de pequenos negócios, lavradores, açougueiros, embarcadiços, oleiros - para citar apenas algumas das atividades ali desenvolvidas - parecem ter partilhado com escravos de ganho e libertos as ruas mais periféricas da cidade. Alguns desses homens e mulheres de diferentes status sociais residiam em ruas como "nas Pedrinhas" ou na "rua da Quitanda", locais onde, possivelmente, os aluguéis tinham um preço mais acessível a essa camada da população economicamente menos favorecida. Foi nesse ambiente que nasceu e viveu até os 10 anos de idade a pequena Maria.

Com uma trajetória de vida oposta à de sua mãe, que nasceu escrava e conquistou a liberdade com a compra de sua alforria, Maria nasceu livre e cruzou a fronteira da liberdade para a escravidão ao ser vendida ilegalmente como escrava em 1830. Embora convivesse diariamente com a escravidão na vila de Jaguaripe - sua própria mãe tinha sido escrava, e outros amigos e conhecidos ainda permaneciam nessa condição -, talvez ela não imaginasse o quanto a escravidão poderia ter faces diversas: a escravidão urbana, mais frouxa, com a qual ela conviveu, e na qual o cativo tinha uma maior mobilidade; e a rural, que viveu na própria pele durante 46 anos. 
Por meio das informações trazidas pelos depoentes no processo de ação de liberdade, aberto em 1876, sabemos que ela viveu livre em companhia de sua mãe até os 10 anos de idade. Durante o tempo em que residiu em Jaguaripe, Maria conviveu com a ausência temporária de sua mãe, quando esta saía da vila para mercadejar em outras praças. Da beira do cais, ela costumava observar o movimento rápido das embarcações que subiam e desciam o rio em direção a Nazaré, Estiva, Aldeia, Maragogipinho e a outros povoados ribeirinhos da região. Ela própria já tinha feito algumas incursões por esses caminhos, sempre em companhia de sua mãe, para povoações mais próximas.

Desde tempos remotos, pequenas embarcações eram utilizadas pela população daquelas localidades "onde barcos, saveiros e canoas, às centenas, faziam o câmbio com as fazendas e os povoados que nasciam perto dos engenhos", como pontuou Isaías Alves (1967: 18). Embora possa ter sido o meio mais rápido para transpor as distâncias entre as povoações, economizando dias de caminhada, nem sempre foi possível para a população mais pobre, fosse livre ou até mesmo escravos de ganho, utilizar esse meio de transporte, pois o preço pago pelo serviço onerava demais aqueles cujos recursos eram parcos.

A opção por fazer o percurso a pé, sujeito a "ataques e roubos", que eram comuns nesses caminhos, nem sempre foi uma alternativa, mas a falta dela. Sozinhas ou em pequenos grupos, mulheres eram vistas nesses caminhos carregando seus balaios com aipins, toucinhos, peixes moqueados, mariscos e outros produtos; barulhentas, passavam cantando e, por vezes, paravam para oferecer os produtos ou para negociar outros. A própria Maria, em diversas oportunidades, esteve ao lado de sua mãe nessas caminhadas.

A proximidade desses povoados de centros maiores, como Nazaré e, até mesmo, a capital Salvador - favorecida pelo uso de embarcações - trouxe àquelas localidades um maior intercâmbio de mercadorias e pessoas. Era comum nas manhãs de sexta e sábado, quando ocorriam tradicionalmente as feiras livres, se observar um fluxo maior de pessoas e mercadorias embarcadas nas pequenas canoas deslocando-se para essas povoações. Ainda na primeira metade do século XIX, o intenso trânsito de pessoas que entravam e saíam das povoações e 0 aumento significativo de queixas de roubo e fuga de escravos e outros crimes cometidos naquelas localidades, onde "vadios e ladrões" encontravam facilmente locais para se acoitar, levaram as autoridades daquelas povoações a empreender um rígido controle sobre a movimentação de pessoas. ${ }^{8}$

De fato, além de ser uma área de atração de pessoas vindas de diversas partes do recôncavo e da capital em busca de trabalho nas fazendas, a geografia do sul do recôncavo também propiciava mil possibilidades de ocultar crimes. Dadas as condições da natureza, a 
qual ofertava largos rios e uma área densamente coberta de Mata Atlântica pouco povoada, a formação de mocambos, quilombos e ranchos que abrigavam todo tipo de gente foi uma realidade da qual as autoridades tinham conhecimento, mas pouco podiam controlar por escassez de pessoal (Gomes, 2015). As diversas correspondências trocadas entre as autoridades municipais e o presidente da Província - cujo teor estava sempre relacionado a questões de segurança - atestam um índice elevado de sujeitos perambulando livremente pelas praças do recôncavo. Indubitavelmente, alguns sujeitos que por ali viviam eram oriundos da escravidão e nunca tinham praticado qualquer tipo de contravenção penal. Para homens e mulheres egressos do cativeiro que logravam meios de sobrevivência, aquele era um ambiente importantíssimo por proporcionar múltiplas alternativas de ganhos. Os homens empregavam-se nos destacamentos policiais, envolviam-se em serviços associados ao comércio local - no abastecimento da cidade de Salvador e outras localidades do recôncavo -, ou, simplesmente, adaptavam-se ao meio ambiente, retirando dos rios e das matas os víveres necessários a sua sobrevivência (Castellucci Jr., 2008: 61).

A esses trabalhadores sazonais misturavam-se mulheres que, vivendo em situação de extrema pobreza, buscavam alternativas de sobrevivência nas vilas e povoados ribeirinhos. 0 ambiente em que circulavam esses homens e mulheres "despossuídos" propiciava, além do trabalho, desentendimentos, brigas, roubos e até mortes que geraram inúmeros processos judiciais, possibilitando aos historiadores uma maior aproximação dos meios de vida praticados por eles e de vivências cotidianas em que se multiplicam formas peculiares de resistência e luta (Dias, 1984). A mobilidade espacial dessa gente pobre livre, apresentada nos diversos documentos da época, também propiciava a "reinserção social" desses indivíduos nas vilas e cidades para onde afluíam em suas andanças, como pontuou Hebe Mattos ao estudar os significados da liberdade no sudeste escravista. Segundo a autora, "o recurso à mobilidade espacial era comum a 'ricos' e 'pobres', mesmo considerando-se as expressivas diferenças que a posse [...] poderia representar nas oportunidades abertas de reinserção social" (Mattos, 2013: 41).

No sul do recôncavo, essa "mobilidade", principalmente de uma "gente de cor", livre e liberta, que entrava e saía das povoações, deixou, em certa medida, as autoridades locais em estado de constante alerta. A postura criada em 1831 refletia bem esse temor. Ficavam, a partir daquela data, proibidos o embarque e o desembarque de indivíduos, nos cais e portos, depois das 22 horas, assim como todo indivíduo que fosse pernoitar naquela povoação teria de apresentar documentos de sua origem. ${ }^{9}$ Com isso, acreditavam as autoridades, estariam inibindo a vadiagem e os crimes contra os "cidadãos de bem", reduzindo os acidentes, assal- 
tos e crimes, o que nem sempre ocorreu. Wellington Castellucci confirma, em suas pesquisas sobre o recôncavo no século XIX, a presença de negros fugidos que buscavam abrigo nessas localidades, a exemplo do cabra Tibúrcio, escravo fugido, que em 1852 morreu na cadeia de Nazaré. 0 mesmo autor sublinha ainda que "era cada vez mais difícil controlar e registrar pessoas que apareciam e logo desapareciam das paróquias pertencentes à Comarca de Nazaré das Farinhas" (Castellucci Jr., 2007: 158). E era, certamente, esse tipo de gente que as autoridades queriam controlar ao criarem a Postura Municipal de 1831.

Ainda que pesasse sobre essa população pobre de cor a obrigatoriedade de apresentar a documentação comprobatória de sua condição e residência, parece que essa exigência pouco inibiu a circulação de foragidos da Justiça e de escravos fugidos, assim como pouco coibiu os constantes furtos de cativos na região, principalmente de crianças escravas, que eram vendidas em outras freguesias. Por meio das informações disponibilizadas nas correspondências entre as autoridades municipais e o presidente da Província, sabemos que, em 1839, circulavam naquela região "indivíduos de má índole" que foram denominados como "passadores de escravos furtados". Além disso, as autoridades denunciavam a necessidade de aumentar 0 corpo policial, visto que a região, além de "abundante de vadios, é mesmo um dos pontos de desembarque de escravos furtados", ${ }^{10}$ o que nos leva a crer que a pequena Maria poderia ter sido levada por um desses indivíduos.

No dia em que foi "roubada alta noite" de Jaguaripe, Maria cumpria tranquilamente a sua rotina diária. Era o mês de setembro, aproximava-se o verão, época em que os mariscos abundavam nos mangues e a fartura de peixes proporcionada pelo rio Jaguaripe trazia renda extra para as mulheres marisqueiras e para aquelas que comercializavam, em tabuleiros, 0 pescado miúdo - moqueado ou in natura - nas vilas. Tal atividade exigia algumas horas longe de casa e, consequentemente, seus filhos menores, que ainda não estavam incorporados a esse mercado de trabalho, teriam de ficar sós ou em companhia de algum parente ou vizinho. Numa sociedade marcada muito mais pelas relações de camaradagem e vizinhança do que de parentesco, estabelecer laços de solidariedade e vizinhança era essencial para a sobrevivência, e Antonia Francisca sabia disso. Ao deixar Maria da Conceição, com apenas 10 anos de idade, aos cuidados de Maria, filha de Rangel de Magalhães, ela acreditava que sua filha estaria segura e ainda teria a oportunidade de aprender a "ler e coser".

Aquele teria sido um dia comum como tantos outros, caso não tivesse Maria desaparecido "repentinamente, sem que sua mãe pudesse descobrir o destino que tivera ella"."1 As circunstâncias do roubo de Maria não são reveladas na documentação, sabemos apenas que ela foi roubada "alta noite" da casa de Rangel de Magalhães e que sua mãe, na manhã 
seguinte, teria saído em busca de informações sobre seu paradeiro, sem sucesso. Os vizinhos de Antonia naquela época informaram que a perda da filha foi um golpe fatal na vida daquela crioula, posto que ela "pouco sobreviveu" ao seu desaparecimento.

Àquela altura - enquanto sua mãe a procurava desesperadamente em Jaguaripe -, Maria já se encontrava em Nazaré das Farinhas na casa de Manoel Ribeiro. Ao que parece, a negociação de sua venda já tinha sido previamente acertada entre o "passador de escravos roubados" Manoel Ribeiro e Francisco Esteves da Conceição (parente e dito procurador de Anna de Jesus, ex-senhora de sua mãe), e, já nos primeiros dias após seu desaparecimento da vila de Jaguaripe, ela já tinha sido conduzida para a freguesia de Santo Antonio de Jesus, onde foi incorporada ao plantel de Félix José Barreto.

Proprietário de muitas terras, Félix Barreto ostentava prestígio e poder naquela freguesia. Seu sítio, denominado Rio da Prata, produzia boa parte do açúcar comercializado na praça de Nazaré. Além do engenho de açúcar, contava ainda com outra propriedade com casa de fazer farinha e um alambique. Seus escravos trabalhavam, de sol a sol, nas extensas lavouras de cana - que parece ter sido a principal atividade daquele sítio -, e também trabalhavam na produção de mandioca e café. Assíduo frequentador das rodas de venda de escravos situadas na praça principal de Nazaré, Felix Barreto negociava e comprava "peças" para atender à crescente demanda por mão de obra de suas propriedades. Naquele mesmo ano de 1830 e em anos seguintes, a família Barreto adquiriu mais 6 escravos: Joaquim, africano, 35 anos de idade; Pedro, cabra, 14 anos de idade; Silvestre, crioulo, 25 anos de idade; Zeferino, crioulo, 20 anos de idade; Eustáquio, crioulo, 30 anos de idade, e um crioulinho de nome Manoel, com apenas 2 anos de idade. ${ }^{12}$ Assim como Maria, todos foram levados para seu sítio.

A vida naquela propriedade rural se diferenciava muito da vida a que a pequena Maria estava acostumada. Em Jaguaripe, vivia livre em companhia de sua mãe e de sua irmã Umbelina; agora, longe de casa, estava cativa e teria de construir, no cativeiro, um espaço mínimo de sociabilidade. Assim como ela, outros escravos recém-comprados passavam a integrar a comunidade já existente de cativos daquela propriedade e, na senzala onde passavam boa parte do tempo quando não estavam na lavoura, buscavam, entre os companheiros de escravidão, encontrar apoio para enfrentar as amarguras da vida em cativeiro. No caso da pequena Maria, com apenas 10 anos, a construção de laços afetivos seria ainda mais importante para superar a separação da mãe e construir, ainda que as condições materiais não a favorecessem, um eventual caminho de volta à liberdade. Sabemos, pelo processo estudado, que a experiência de liberdade vivida por Maria continuou em suas lembranças, definindo-se em oposição à escravidão à qual foi submetida. As diversas tentativas frustradas de fuga empreendidas por ela revelam sua inconformidade com tal situação. ${ }^{13}$ 
Segundo ela própria relatou, durante o tempo que esteve cativa, "fez diversas tentativas para ir a supra dita villa [de Jaguaripe] tractar de sua liberdade, mas seus esforços para esse fim forão sempre frustrados, sendo ella suplicante presa por duas vezes em caminho para a mesma...". ${ }^{14}$ No contexto das fazendas, sítios e pequenas propriedades do interior rural do sul do recôncavo, onde a lida diária nas lavouras de cana, mandioca e café ocupava boa parte do tempo de trabalho, poucos eram os espaços de autonomia e as possibilidades de que um escravo podia valer-se para se ausentar do cativeiro. Essa foi, certamente, uma dificuldade que Maria vivenciou em seu cativeiro na zona rural do recôncavo.

Nas fazendas da região, uma possível "autonomia" escrava estava ligada muito mais à concessão de um pedaço de terra para o cultivo de subsistência e de uma casa - na própria propriedade - onde pudesse habitar com sua família do que à possibilidade de mobilidade espacial experimentada por cativos, que vivenciaram a experiência da escravidão urbana, como ficou evidente na linha de defesa apresentada pelo advogado dos réus no processo de ação de liberdade. Segundo este, a mobilidade espacial vivenciada por Antonia Francisca, mãe da cabra Maria, refletia muito mais uma concessão feita pelo senhor, que permitia que seus escravos "residissem fora de casa e athe mesmo fora do município de sua residência com a obrigação do estipêndio semanário, ou mensal". Essa permissão estava longe de constituir-se em "direito à prescrição do captiveiro" ou "de direito à liberdade". ${ }^{15}$

Embora essa concessão dependesse, obviamente, da boa vontade do senhor, a situação descrita pelo advogado em sua defesa evidencia ainda que, em alguns casos, o escravo urbano podia migrar e fixar residência em outros municípios, situação que se opunha diametralmente ao que vivenciava o escravo do mundo rural, obrigado a se fixar nas terras do seu senhor, condição na qual agora vivia Maria. Se as evidências revelam as poucas oportunidades de mobilidade espacial do escravo rural, elas não negam que esses cativos, embora "presos à terra", conseguiram estabelecer relações com libertos e pobres livres, assim como com outros escravos de propriedades diferentes. Pelo menos é o que se observa nos registros de casamento e batismo ao se estudar acerca dos laços de solidariedade e família escrava (Barreto, 2016: 76-111).

Sem conseguir provar sua condição de livre, nasce no cativeiro, em 1841, Josefa, sua primeira filha. Naquela época, onze anos após sua chegada àquela propriedade, ela contava 21 anos de idade, e ainda permanecia na condição de escravizada no sítio Rio da Prata. Sua segunda filha, Leandra, nasceu em 1848, 7 anos após o nascimento de Josefa. Assim como a maioria das mulheres cativas daquela região, Maria não formalizou sua união consensual na igreja, e suas duas filhas engrossavam o número de crias ilegítimas daquela propriedade. A 
documentação não nos possibilita saber por quanto tempo Maria manteve o relacionamento com o pai de suas filhas, tampouco se as duas eram fruto de uma mesma relação.

Ainda no cativeiro, Maria experimentou o contato com pessoas livres de cor, assim como com ex-escravos que, sazonalmente, atuavam na propriedade em que ela era cativa. Parece ter sido comum, no interior da área estudada, assim como o foi em outras áreas do Brasil oitocentista, a presença de trabalhadores temporários: jornaleiros que permaneciam por algum tempo na propriedade. No sítio Rio da Prata, o emprego de trabalhadores temporários, especializados ou não, parece ter sido comum. João Evangelista de Sousa Cajueiro, 38 anos de idade, natural de Nazaré das Farinhas, por exemplo, trabalhou "cerca de dois anos" como pedreiro naquela propriedade. Assim como ele, outros trabalhadores livres podem ter vivido temporariamente ali, o que teria criado possibilidades de relacionamentos afetivos entre cativas e indivíduos de outros estratos sociais. Embora os senhores pouco se interessassem pelos "tratos ilícitos" praticados por suas escravas e escravos, do ponto de vista econômico parece ter sido bastante interessante para eles que essas relações dessem frutos. Afinal, em tempos de crise de mão de obra, sobretudo após a lei de 1850, esses novos escravos movimentariam o comércio de cativos naquela região.

Entre os anos de 1868 e 1871, foram negociados 82 escravos na freguesia de Santo Antonio de Jesus. Desses, 24 eram crianças com idades entre 6 meses e 12 anos, representando quase $30 \%$ do total de escravos comercializados. Outro dado chama ainda mais a nossa atenção: das 24 crianças vendidas, apenas 7 (29\%) foram comercializadas com suas mães, enquanto a maioria, ou seja, 71\%, foram vendidas sozinhas, sem a companhia de suas progenitoras. Apesar da determinação da lei de 25 de agosto de 1869, que proibia separar a mãe dos filhos, "exceto quando o filho tivesse mais de 15 anos de idade" (Conrad, 1978: 107), e das pesadas multas previstas para o seu não cumprimento, parece que 0 atendimento a esta foi negligenciado tanto pelos proprietários de escravos quanto pelos tabeliães que atestaram tais vendas. Ainda que o comércio de crianças sós, sem seus pais, tenha sido uma prática comum de senhores escravocratas naquela região, como apontam as fontes, alguns senhores mantinham mães e filhos convivendo na mesma propriedade durante muitos anos, como ocorreu com a então escrava Maria da Conceição, que viveu com suas duas filhas e três de seus netos até o falecimento de Felix Barreto, em 1864.

Sem qualquer possibilidade de mobilizar-se para obter sua liberdade, Maria e sua família mantiveram-se sob a posse de Felix Barreto até 1864, quando a morte daquele senhor foi anunciada, e a partilha dos seus bens foi efetivada. 0 falecimento daquele senhor promoveu uma verdadeira reviravolta na vida de Maria da Conceição. Trinta e quatro anos haviam se 
passado desde que ela fora "roubada e vendida com escrava"; sua família crescera e, àquela época, ela já era mãe de duas mulheres e avó de três netos - Marcelino, Manoel e Belmira -, filhos de Josefa, a mais velha, e todos residiam na mesma propriedade. Entretanto, de repente, chegou a notícia de que ela e Leandra, sua filha de 16 anos, tinham sido aquinhoadas a Ignácio Dias Barreto, um dos filhos daquele senhor, enquanto Josefa e seus três filhos permaneceriam morando na antiga propriedade com a proprietária Francisca Maria de Jesus, viúva de Felix Barreto. Logo depois dessa primeira separação, ocorrida em 1864, outra separação transferiu Leandra, por dote, para a posse de Severiano Sampaio de Oliveira Sandes. Naquela época, sua família foi dividida entre os herdeiros de Felix Barreto, e parecia pouco provável que ela conseguisse reverter aquela situação.

No decorrer dos doze anos em que esteve em posse de Ignácio Dias Barreto (18641876), Maria acompanhou, mesmo que distante, o nascimento de mais cinco netos (Leandro e Marcolino, filhos de Josefa; e Julio, Primitivo e Maria, filhos de Leandra) e o infortúnio da morte de Belmira, sua neta, filha de Josefa, com apenas 10 anos de idade. Assim como ela própria, suas filhas não formalizaram uma união, e seus netos nasceram como escravos, frutos de relações amorosas vividas por suas mães no cativeiro.

Em 1875 nasceu Maria, filha natural de Leandra e última neta de Maria da Conceição, fechando assim a rede familiar iniciada por Antonia Francisca, escrava de ganho que conquistou sua liberdade com o fruto de seu trabalho nas primeiras décadas do século XIX. A terceira geração de mulheres daquela família nasceu e viveu, por um longo período, sob o regime da escravidão rural, na freguesia de Santo Antonio de Jesus, ainda que a matriarca Antonia Francisca tivesse lutado para iniciar sua família fora do cativeiro, ao ter se alforriado nas primeiras décadas do século XIX, como indicam as fontes analisadas.

\section{O INÍCIO DO FIM...}

M uitos anos haviam se passado, e Maria ainda guardava na memória o tempo em que vivera livre na vila de Jaguaripe, e foi, provavelmente, essa memória que manteve acesa sua esperança de um dia conseguir provar sua condição de livre. Grande parte de sua trajetória sob o domínio dos familiares de seu primeiro senhor permaneceu ofuscada pela ausência de informações. No entanto, em 1876, ao ser negociada em uma transação de compra e venda feita entre Ignácio Dias Barreto e Maria Josefina de Andrade, Maria pôde, mais uma vez, sonhar com a liberdade. 
Sob a posse desta senhora, e antes mesmo que a transação tivesse sido registrada em cartório, Maria da Conceição, com 56 anos de idade, conseguiu, pela primeira vez, consentimento para se ausentar do cativeiro e ir à vila de Jaguaripe, onde obteve um "mandado de manutenção de liberdade" expedido pelo juiz municipal daquela localidade, tendo em vista a ação de liberdade a que finalmente dera início contra seus "pretensos" senhores, ação que, como dito anteriormente, se estendia à sua prole.

Não sabemos ao certo quais argumentos ela utilizou para que Maria Josefina de Andrade, sua senhora naquela oportunidade, a deixasse ir à vila de Jaguaripe. É bem possível que ela tenha sido adquirida para servir de escrava de ganho e, como tal, tenha recebido permissão para ir à dita vila (embora os autos não revelem tal atividade). Dificilmente a senhora soubesse o real motivo da escrava, ou, se o soubesse, o fez acreditando que não perderia seu investimento.

A obtenção da autorização para se ausentar do cativeiro foi apenas a primeira vitória conquistada por Maria na difícil caminhada que ainda teria que empreender na busca da liberdade de si mesma, de suas filhas, e de seus netos. Sua viagem até a vila de Jaguaripe, desde o início, foi arriscada. Afinal, atravessar grande extensão territorial, a pé, sozinha e sem recursos, por caminhos abertos nas matas, enfrentando todo tipo de dificuldade, até Nazaré e, de lá, com sorte, conseguir alguma embarcação que a levaria à vila de Jaguaripe, não parece ter sido tarefa fácil.

A documentação judicial com a qual trabalhamos para compor a história de vida dessa mulher negra, escravizada ilegalmente, não nos possibilita saber, ao certo, quanto tempo ela levou em sua viagem até Jaguaripe, tampouco se estava sozinha ou em companhia de algum camarada durante sua empreitada. Tudo leva a crer que Maria não arquitetou sozinha seu plano, pois seria muito difícil para uma escrava, principalmente para uma escrava pertencente a uma freguesia rural como a de Santo Antonio de Jesus, conseguir voz na Justiça. As possíveis alianças tecidas por Maria foram apontadas nas alegações interpostas pelo advogado dos réus (herdeiros de Felix Barreto).

Ainda que, muitas vezes, essas alianças não apareçam de forma explícita nos autos (pelo menos na ação de liberdade que analisamos, a ligação de Maria "com quem a protege" não revela quem são, tampouco qual o grau de envolvimento, desta ou destas pessoas, com a sua causa de liberdade), não podemos negar que "o acesso à estrutura jurídica e ao judiciário dependia, e muito, das relações pessoais que o escravo mantivesse com homens livres e poderosos do local", como bem avaliou Keila Grinberg (2008: 37-38). É possível, portanto, que ela tenha conseguido auxílio dos componentes da rede de amizade que construiu ainda no 
cativeiro: indivíduos, a exemplo do pedreiro João Evangelista, morador na cidade de Nazaré, ou até mesmo do comerciante José Osório Galdino, os quais mais tarde figurariam no rol das testemunhas do processo.

Em situações nas quais era necessário provar sua condição de libertos, e, no caso de Maria, pessoa livre escravizada de forma ilegal, a proteção de pessoas livres bem estabelecidas foi de extrema importância para provar seu status. No caso de Ovídia, tratado por Maria Helena Machado, fica evidente a ligação que essa mulher estabeleceu ao longo de sua vida com homens livres, da qual ela lançou mão ao se ver nas garras da Justiça (Machado, 2010). Assim como a história dela, outras histórias, como a de Adelaide, provável liberta, que perambulou por Cuba e pela Luisiana nos primeiros anos do século XIX, aludida por Rebeca Scott (2009), revelam os vínculos que constituíram durante suas vidas. São mulheres que, embora presas ao mundo do cativeiro, conquistaram redes de proteção importantes, tanto para a sua sobrevivência local quanto para empreender possíveis deslocamentos geográficos em busca de melhores condições de vida.

Toda ação judicial proposta por um escravo deveria ser impetrada por uma pessoa livre que assinaria o requerimento "a rogo" dele. Assim, antes mesmo de ser instaurada a ação, o escravo teria de ter acesso a um curador que o representaria judicialmente: "sem um curador, a ação não prossegue" (Grinberg, 2008: 37). Diante de tal fato, para o indivíduo que se encontrava em situação de escravidão, viabilizar uma possível ação contra seu senhor significava, em primeiro lugar, estabelecer relações sociais com pessoas que pudessem aproximá-lo do mundo dos livres (ibidem: 39), assim como reunir o maior número de informações possíveis para compor a justificativa a ser apresentada ao juiz. Sem essas prerrogativas, dificilmente 0 escravizado lograria sucesso em sua empreitada.

0 processo de ação de liberdade movido por Maria da Conceição é um dos onze que localizei no Arquivo Público do Estado da Bahia (Apeb) que, durante o século XIX, chegaram ao Tribunal da Relação vindos da comarca de Nazaré. A leitura desses processos chama a atenção para a capacidade dos cativos de criar redes e artifícios capazes de proporcionar a eles a transição da escravidão à liberdade pelos meios "legais". Ainda que submetidos a todo tipo de vicissitudes e adversidades impostas pelo cativeiro, pelos rígidos quadros do domínio escravista, como o isolamento rural imposto a Maria, nossa personagem, fica evidente, nos processos, a capacidade de criar artifícios de sobrevivência que iriam além da sua existência material e que, efetivamente, aumentariam suas chances de alcançar o sonho de ser livre.

É bastante revelador, nesse sentido, observar as estratégias criadas e recriadas por eles para atingir seus objetivos. Nas circunstâncias em que vivia Maria, iniciar o processo na vila 
de Jaguaripe, longe do raio de influência daquele senhor que a escravizava, Ihe garantiria, provavelmente, uma maior possibilidade de conseguir alguém que aceitasse participar de tal empreitada judicial. Em Nazaré e na freguesia de Santo Antonio de Jesus, ela dificilmente teria tido sucesso devido ao grande prestígio e poder que exercia a família Barreto na região.

Não foi à toa que ela enfrentou, bravamente, vários dias de caminhada até a vila de Jaguaripe, de onde sairia com um documento de manutenção de liberdade expedido pelo juiz municipal. Iniciava-se, assim, em 1876, década em que foi promulgada a primeira lei abolicionista brasileira (a Lei do Ventre Livre), um longo processo de ação de liberdade que envolvia nove cativos: Maria da Conceição, suas duas filhas e seis netos. Àquela época, sua neta Belmira já havia falecido.

A batalha judicial entre a "escrava" Maria e seus senhores revelou aspectos interessantes para se pensar o direito no Brasil escravista do Oitocentos, no que diz respeito ao transito da escravidão para a liberdade (ainda que esta não seja nossa principal linha de investigação). Os calorosos debates empreendidos por curadores, advogados dos réus e juízes contra e a favor da causa da liberdade, revelam além da apresentação das leis, a força dos costumes e das relações de poder ali existentes. Iluminam, segundo Hebe (Mattos, 2013), as tensões entre arbítrio e legitimidade do poder senhorial. Assim como, expõe a vasta rede de relações familiares e comunitárias construídas no cativeiro e fora dele (ibidem: 183).

Maria, na condição de escrava em que se encontrava, legalmente não poderia ter sido mantida em liberdade durante o trâmite do processo. No entanto, ela saiu de Jaguaripe de posse de um documento de "manutenção de liberdade", quando deveria, pela lei, ter sido depositada, como escrava que era, até que a ilegitimidade do cativeiro fosse provada. Ainda que os advogados dos réus tenham contestado tal ação do juiz, ela não foi revogada, e Maria acompanhou todo o processo em liberdade. Suas filhas e netos não tiveram a mesma sorte. Durante o tempo em que durou a batalha judicial, eles sofreram todo o tipo de atrocidades.

Mantidas em posse de seus senhores, Josefa e Leandra só conseguiram ser depositadas em janeiro de 1877, quase 7 meses após o início do processo, por força das alegações que revelaram "rigorosos castigos que constantemente sofrem de palmatória, correia e troncos" como aponta a petição apresentada pelo curador de sua mãe, e depois de terem sido "jogadas" no depósito público da cidade de Nazaré, lugar "notoriamente insalubre", e que "muito pode prejudicar a saúde dos suplicantes e dos referidos menores", por falta de um depositário legal. Ainda assim, dois de seus netos, Julio e Primitivo, filhos de Leandra, continuaram em posse de Severiano Sampaio até o final do processo. 
Quando a sentença foi publicada, em 9 de agosto de 1877, já havia se passado mais de um ano do início da ação, e ela foi totalmente favorável à causa da liberdade. Imediatamente após a publicação da sentença, os curadores de Maria solicitaram o "levantamento do depósito" de suas filhas e netos, e um mandado de apreensão e entrega dos menores ingênuos Julio e Primitivo, que se achavam, até aquela época, em poder de Severiano Sampaio.Os autos não revelam em quais condições aquela família viveu durante o tempo em que tramitou o processo no Tribunal da Relação; sabemos, no entanto, que elas não mais estavam sob o poder de seus "pretensos" senhores. Entretanto, a notícia da sentença deve ter surpreendido Maria da Conceição, que, àquela altura, havia mais de um ano vivia com suas filhas e netos, livremente, sem ser importunada.

\section{CONSIDERAÇÕES FINAIS}

vida de Maria da Conceição, retratada no processo de ação de liberdade, trouxe impor-
tantes informações sobre a escravidão no mundo rural e urbano do sul do recôncavo na segunda metade de século XIX. Questões sobre espaço de autonomia no cativeiro, construção de laços de solidariedade e o estabelecimento de sólidas relações familiares e pessoais entre escravos - fossem de uma mesma propriedade ou não - libertos e mesmo pobres livres que circulavam em busca de trabalho temporário naquelas propriedades são temas apresentados nas diversas falas das testemunhas, advogados e curadores.

A trama que envolveu Maria, suas duas filhas e sete netos, revelou experiências complexas de luta. Sucessos/fracassos, perdas/ganhos fizeram parte do fluxo permanente na vida dessa mulher. Constatar isso pode ser pouco, mas são histórias como essas que abrem caminhos para se analisar um universo mais amplo de questões envolvendo muIheres negras escravizadas.

\section{NOTAS}

1 Arquivo Público de Estado da Bahia (Apeb).Processo crime,12/481/05. Depoimento da escrava Felicidade, Jaguaripe, 1864.

2 Ibidem.Processo civil, 47/1666/14, Depoimento de Manoel Hygino de Seixas, 1877.

3 Ibidem.Processo civil, 47/1666/14, Depoimento de Úrsula Antonia da Conceição, 1877.

4 Ibidem.Processo civil, 47/1666/14, Depoimento de Úrsula Antonia da Conceição, 1877.

5 Ibidem.Processo civil, 47/1666/14, Depoimento de Athanasio Rodrigues, 1877. 
6 RECENSEAMENTO DO Brazil em1872. Bahia. Rio de Janeiro: Typ. G. Leuzinger, [1874?]. V.3. Disponível em:<https://biblioteca.ibge.gov.br/visualizacao/livros/liv25477_v3_ba.pdf>. Acesso em: 29 de maio de 2012.

7 Além dos registros dos viajantes oitocentistas, os dados apresentados pelo censo de 1872, comparados com o quadro da polícia datado de 1838, são reveladores nesse sentido.

8 Apeb. Seção Colonial/provincial. Série Presidência da Província. Correspondências da Câmara Municipal da vila de Jaguaripe ao Presidente de Província. 1832-1838, Maço 1.332. Série Judiciário - Juízes Nazaré. 1839-1842, Maço 2.503.

9 Ibidem. Seção Colonial/provincial, 04/1437/10, 1831.

10 Ibidem. Seção Colonial/Provincial. Série Judiciário - Juízes de Nazaré, 1839-1842. Maço 2.503.

11 Ibidem. Processo civil, 47/1666/14. Alegação do advogado das autoras, Ação de Liberdade, 1877.

12 Ibidem. Livro de Notas do Tabelião, 1830-1875 - Santo Antonio de Jesus.

13 o processo revela que Maria foi "presa por duas vezes em caminho para a vila de Jaguaripe". Ibidem. Processo civil, 47/1666/14. Ação de Liberdade, Maria da Conceição, 1877.

14 Ibidem. Processo civil, 47/1666/14. Ação de Liberdade, Maria da Conceição, 1877. (Grifo nosso)

15 Ibidem. Processo civil, 47/1666/14. Ação de Liberdade, Defesa do advogado dos réus, 1877.

16 Ibidem.Processo civil, 47/1666/14. Ação de Liberdade, Maria da Conceição, 1877.

\section{REFERÊNCIAS BIBLIOGRÁFICAS}

ABRAHÃO, Fernando A. As ações de liberdade de escravos do tribunal de Campinas. Campinas: Unicamp Centro de Memória, 1992.

ANDRADE, Maria José de Souza. A mão de obra escrava em Salvador (1811-1860). São Paulo/Brasília: Corrupio/CNPq, 1988.

ALVES, Isaías. Matas do sertão de baixo. Rio de Janeiro: Reper Editora e Publicidade, 1967.

BARRETO, Virgínia Queiroz. Fronteiras entre a escravidão e a liberdade: histórias de mulheres pobres livres, escravas e forras no recôncavo sul da Bahia (1850-1888). 2016. Tese (Doutorado em História Social) - Faculdade de Filosofia, Letras e Ciências Humanas, Universidade de São Paulo, São Paulo. 2016.

CASTELLUCCI Jr., Wellington. Pescadores e roceiros: escravos e forros em Itaparica na segunda metade do século XIX, 1860-1888. São Paulo/Salvador: Annablume; Fapesp/ Fapesb, 2008.

. A forca e o machado: resistência escrava e cotidiano de libertos na Comarca de Nazareth das Farinhas. Recôncavo baiano, 1830-1852. Revista de História, Universidade de São Paulo, n. 156, p. 157-191, jun. 2007.

COWLING, Camilia. 0 fundo de emancipação "Livro de Ouro" e as mulheres escravizadas: gênero, abolição e os significados da liberdade na Corte, anos 1880. In: XAVIER, Giovana; FARIAS, Juliana; GOMES, Flávio. MuIheres negras: no Brasil escravista e do pós-emancipação. São Paulo: Selo Negro Edições, 2012. p. 214-227.

CONRAD, Robert. Os últimos anos da escravatura no Brasil, 1850-1888. Rio de Janeiro: Civilização Brasileira, 1978. 
CHALHOUB, Sidney. Visões da liberdade: uma história das últimas décadas da escravidão na Corte. São Paulo: Companhia das Letras, 1990.

DIAS, Maria Odila Leite da Silva. Quotidiano e poder em São Paulo no século XIX. São Paulo: Brasiliense, 1984.

FARIAS, Juliana Barreto. Mercados minas: africanos ocidentais na Praça do Mercado do Rio de Janeiro (18301890). Rio de Janeiro: Arquivo Geral da Cidade, 2015.

GOMES, Flávio dos Santos. Mocambos e quilombos: uma história do campesinato negro no Brasil. São Paulo: Claro Enigma, 2015.

GRINBERG, Keila. Liberata: a lei da ambiguidade - as ações de liberdade da Corte de Apelação do Rio de Janeiro no século XIX. Rio de Janeiro: Centro Edeistein de Pesquisas Sociais, 2008.

MACHADO, Maria Helena P. T. Corpo, gênero e identidade no limiar da abolição: a história de Benedicta Maria Albina da Ilha ou Ovídia, escrava (Sudeste, 1880). Revista Afro-Ásia,Salvador, n.42, p. 157-193, 2010.

MATTOS, Hebe. Das cores do silêncio: os significados da liberdade no Sudeste escravista (Brasil, século XIX). 3. ed. Campinas: Editora da Unicamp, 2013.

PAIVA, Eduardo França. Mulheres de diversas "qualidades" e seus testamentos na colonial, escravista e mestiça capitania das Minas Gerais. In: XAVIER, Giovana; FARIAS, Juliana; GOMES, Flávio. Mulheres negras: no Brasil escravista e do pós-emancipação. São Paulo: Selo Negro Edições, 2012. p. 11-23.

PAIXÃO, Marcelo; GOMES, Flávio. História das diferenças e das desigualdades revisitadas: notas sobre gênero, escravidão, raça e pós-emancipação. In: ; XAVIER, Giovana; FARIAS, Juliana. Mulheres negras: no Brasil escravista e do pós-emancipação.São Paulo: Selo Negro Edições, 2012. p. 297-313.

SCOTT, Rebecca J. 'She...Refuses to Deliver Up Herself as the Slave of Your Petitioner': Émigrés, Enslavement, and the 1808 Louisiana Digest of the Civil Laws (Symposium on The Bicentennial of the Digest of 1808--Collected Papers)". Tulane European and Civil Law Forum, v. 24, p. 115-136, 2009.

SOARES, Cecília Moreira. As ganhadeiras: mulher e resistência negra em Salvador no século XIX. Afro-Ásia, Salvador, n. 17, p. 57-71, 1996.

WISSENBACH, Maria Cristina Cortez. Sonhos africanos, vivências ladinas: escravos e forros em São Paulo (1850-1888). São Paulo: Hucitec/Programa de História Social - USP, 1998. 
